\title{
FAKTOR-FAKTOR YANG MEMENGARUHI FOREIGN DIRECT INVESTMENT (FDI) DI ENAM KORIDOR EKONOMI INDONESIA: MARKET SEEKING ATAU RESOURCE SEEKING?
}

\author{
Iriani Trisna Rahayu ${ }^{1}$ dan Ernawati Pasaribu ${ }^{2}$ \\ ${ }^{1}$ Badan Pusat Statistik Propinsi Papua Barat, Jakarta \\ ${ }^{2}$ Dosen Statistika, Sekolah Tinggi Ilmu Statistik, Jakarta \\ e-mail: ${ }^{2}$ ernapasaribu@stis.ac.id
}

\begin{abstract}
Abstrak
Pembangunan ekonomi suatu negara sangat tergantung pada besarnya penanaman modal asing langsung atau Foreign Direct Investment (FDI), termasuk di enam koridor ekonomi Indonesia. Kesenjangan kondisi di koridor ekonomi diperkirakan akan membawa perbedaan yang mempengaruhi arus masuk FDI ke dalam koridor. Penelitian ini menggunakan regresi data panel untuk menganalisis faktor-faktor di balik arus masuk FDI di setiap koridor ekonomi dan untuk menentukan karakteristik FDI di setiap koridor ekonomi. Hasil penelitian menunjukkan bahwa proporsi belanja modal pemerintah, jumlah angkatan kerja berpendidikan tinggi, keterbukaan perdagangan, dan proporsi ekspor minyak dan mineral hanya mempengaruhi arus masuk FDI di beberapa koridor ekonomi. Lebih jauh lagi dapat diindikasikan bahwa sementara "market seeking FDI" terjadi di semua koridor ekonomi Indonesia, "resource seeking FDI" hanya ditemukan di koridor ekonomi Sulawesi, Maluku dan Papua.
\end{abstract}

Kata kunci: FDI, Koridor Ekonomi, data panel, market seeking, resource seeking

\begin{abstract}
The economic development of a country depends on the amount of foreign direct investment (FDI), including in the Indonesian six economic corridors. The huge gaps of conditions in economic corridors are expected to differences infactors affecting the FDI-inflow into the corridors. This study uses a panel data regression to analyze factors behind the FDI-inflow in each economic corridor and to determine the FDI characteristic in each economic corridor. It shows that the proportion of government capital expenditure, number of highly-educated labor force, trade openness, and the proportion of oil and mineral export affect the FDI-inflow only in some economic corridors. Furthermore, it indicates that, while market seeking FDI occurred in all Indonesian economic corridors, resource seeking FDI was only found in Sulawesi, Maluku and Papua economic corridors..
\end{abstract}

Keywords: Foreign Direct Investment (FDI), Indonesian economic corridors, panel data regression, market seeking, resource seeking 


\section{PENDAHULUAN}

Pasca krisis tahun 1997, pemerintah mulai memperbaiki diri, terutama untuk membangkitkan perekonomian yang terpuruk. Hasil dari pembangunan yang terus digalakkan pemerintah, baik di pusat maupun di daerah tersebut, dapat terlihat dari perkembangan ekonomi Indonesia yang pada umumnya mengalami pertumbuhan yang positif.

Akan tetapi, mulai tahun 2007, tingkat pertumbuhan ekonomi Indonesia semakin melambat. Hal ini menunjukkan bahwa program pembangunan ekonomi yang selama ini dijalankan oleh pemerintah kurang memberikan hasil yang maksimal untuk percepatan pembangunan ekonomi Indonesia dalam jangka panjang. Oleh karena itu, pemerintah mencoba melakukan transformasi ekonomi, yaitu pengalihan perekonomian Indonesia yang awalnya didasari oleh konsumsi menjadi perekonomian yang didasari oleh investasi (Bappenas, 2011).

Di sisi lain, dalam upaya menjadikan Indonesia sebagai negara maju dan sejahtera tahun 2025, pemerintah menyusun rencana pembangunan yang difokuskan pada pengembangan sejumlah kegiatan ekonomi utama masing-masing wilayah Indonesia. Rencana tersebut tertuang dalam Masterplan Percepatan dan Perluasan Pembangunan Ekonomi Indonesia (MP3EI) melalui Peraturan Presiden Nomor 32 tahun 2011. MP3EI tersebut membagi wilayah Indonesia menjadi koridor-koridor ekonomi berdasarkan pada keunggulan dan potensi sektoral masing-masing wilayah. Sistem koridor ini mengacu pada kesuksesan sistem koridor ekonomi yang diterapkan negaranegara Asia lainnya. Indonesia menetapkan enam koridor ekonomi, yaitu Koridor Sumatera, Koridor Jawa, Koridor Kalimantan, Koridor Bali dan Nusa Tenggara, Koridor Sulawesi, serta Koridor Maluku dan Papua. Dengan adanya korodor ini, para investor akan lebih mudah dalam menentukan jenis investasi yang akan dilakukan, yaitu pada sektor ekonomi apa dan di mana.

Transformasi ekonomi yang digunakan sebagai alat untuk merealisasikan
MP3EI tersebut tentu membutuhkan sumber daya dan dana yang tidak sedikit. Sumber daya alam yang berlimpah serta jumlah penduduk yang sangat besar mungkin bukan merupakan masalah. Namun dana yang dapat disediakan oleh pemerintah sangatlah terbatas. Oleh sebab itu, dibutuhkan suntikan dana dari swasta, baik dari dalam negeri maupun dari luar negeri.

Salah satu sumber dana yang besar dan dapat segera digunakan adalah Investasi Asing Langsung atau Foreign Direct Investment (FDI). Investasi jenis ini lebih menguntungkan dibandingkan dengan investasi yang tidak langsung. Berbeda dengan investasi tak langsung, seperti investasi porto folio yang bisa tiba-tiba ditarik oleh investor, FDI lebih bersifat komitmen jangka panjang, sehingga dianggap lebih bernilai bagi suatu negara.

Namun, realisasi FDI di Indonesia ternyata belum merata di semua koridor ekonomi. Selaras dengan pembangunan yang berpusat di Jawa, FDI yang masuk ke Indonesia pun sebagian besar masih berada di koridor Jawa. Bahkan persentase (share) FDI di koridor Jawa dalam periode 19972014 selalu lebih dari 50\% dari total FDI Indonesia.

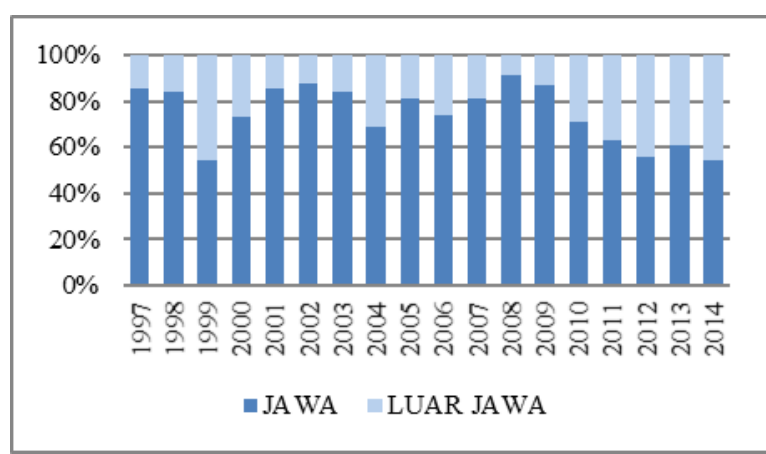

Sumber: Badan Koordinasi Penanaman Modal (BKPM, diolah)

\section{Gambar 1.Persentase Realisasi FDI di Indonesia menurut Jawa dan Luar Jawa, 1997-2014}

Oleh karena itu, penelitian ini bertujuan untuk menganalisis faktor-faktor yang memengaruhi FDI di masing-masing koridor ekonomi Indonesia. Penelitian ini juga bertujuan untuk menganalisis motivasi apakah yang melatarbelakangi investor asing untuk menanamkan modalnya di 
Indonesia, apakah market seeking atau resource seeking.

\section{KAJIAN PUSTAKA}

Menurut Todaro \& Smith (2003), FDI merupakan investasi yang dilakukan oleh pihak swasta asing, yang mana dana-dana investasinya langsung digunakan untuk menjalankan kegiatan bisnis seperti mendatangkan mesin-mesin dan membeli bahan baku produksi. Teori elektikal Dunning (1993) menyebutkan bahwa keunggulan yang harus dimiliki oleh suatu negara untuk menarik investasi asing adalah antara lain biaya produksi rendah (termasuk transportasi), tersedianya pasar yang besar (market size), sumber daya yang melimpah (meliputi SDA dan tenaga kerja berupah rendah yang terampil), serta minimnya hambatan perdagangan dan tingkat keterbukaan ekonomi.

Dunning

(1993) kemudian menyimpulkan bahwa beberapa hal yang melatarbelakangi investor asing untuk menanamkan modalnya di suatu negara dapat dikelompokkan ke dalam alasan market seeking dan atau resource seeking. Market seeking merupakan jenis investasi asing yang ditujukan untuk mencari pasar baru atau mempertahankan pasar lama. Sedangkan resource seeking adalah jenis investasi yang dilakukan untuk mendapatkan faktor-faktor produksi yang berbentuk sumber daya alam atau tenaga kerja yang lebih efisien di negara lain dibandingkan dengan di negara sendiri.

Penelitian terdahulu menunjukkan adanya beberapa faktor penting yang berpengaruh terhadap masuknya FDI ke suatu negara, yaitu market size, ketersediaan Sumber Daya Alam (SDA) dan Sumber Daya Manusia (SDM), infrastruktur, dan kebijakan perdagangan serta kondisi perekonomian negara tujuan (Jadhav, 2012; Hsiao \& Hsiao, 2004; Asiedu, 2006, Rohmana, 2011; Sarwedi, 2002; Setiawan, 2002). Besarnya pasar atau market size akan memengaruhi keputusan investor untuk menanamkan modalnya ke negara tujuan, khususnya bagi investor yang ingin mengembangkan jangkauan pasarnya
(Asiedu, 2002). Dengan demikian, Indonesia yang merupakan salah satu negara dengan jumlah penduduk terbanyak di dunia merupakan sebuah pasar besar bagi investasi asing.

Meskipun PDB per kapita Indonesia tidak termasuk ke dalam golongan pendapatan tinggi, namun pola konsumsi masyarakat Indonesia masih cenderung konsumtif. Hal tersebut terbukti dari besarnya konsumsi masyarakat dilihat dari unsur PDB pengeluaran, dibandingkan dengan pengeluaran untuk investasi. Rendahnya investasi dan tingginya konsumsi inilah yang menjadi salah satu penyebab mengapa pembangunan ekonomi di Indonesia tidak bisa berlangsung pesat.

Tingginya pola konsumsi masyarakat Indonesia dan ditambah dengan upah yang masih rendah menjadi faktor lain yang dapat menarik FDI ke Indonesia. Perusahaan Multinasional bisa saja memberikan upah yang sedikit lebih tinggi dibandingkan dengan upah dari perusahaan dalam negeri, ataupun perusahaan pesaing, yang mana sebenarnya jika dibandingkan dengan upah di negara asalnya masih jauh lebih rendah. Tenaga kerjanya pun mempunyai skill yang cukup bagus jika dibandingkan dengan negara berkembang lainnya.

Selain akses terhadap SDM, akses terhadap Sumber Daya Alam (SDA) di Indonesia juga cukup mudah karena masih melimpahnya SDA di Indonesia. Bagi negara sedang berkembang,seperti Indonesia, ketersediaan SDA merupakan daya tarik bagi investor asing, terutama yang bergerak di industri primer (Jadhav, 2012).

Sebaliknya, langkanya SDA di negaranegara maju memberikan peluangbagi produk ekspor negara sedang berkembang yang bernilai ekonomis.(Asiedu \& Lien, 2010). Investor asing akan lebih memilih untuk terjun langsung sebagai pengekspor di negara tujuan karena akan memberikan keuntungan yang lebih besar dibandingkan dengan mengimpor di negaranya sendiri.

Faktor lain yang menjadi penarik investor asing adalah kemudahan akses, melalui ketersediaan fasilitas umum dan infrastruktur. Kemudahan akses ini menjadi faktor penting bagi investor, khususnya di 
Indonesia, tterbukti dari realisasi FDI yang lebih dari $50 \%$ di koridor Jawa yang disebabkan karena selama ini pembangunan infrastruktur yang masih berpusat di koridor Jawa. Kemudahan akses serta tersedianya fasilitas dan infrastruktur akan memudahkan investor, baik dalam proses produksi maupun dalam pendistribusian produk.

Akan tetapi, masuknya investasi asing, khususnya FDI juga sangat tergantung pada kebijakan makroekonomi dan kebijakan perdagangan di negara tujuan. Suatu negara yang menganut sistem ekonomi tertutup tidak akan membuka peluang bagi investor asing untuk menanamkan modal di negara tersebut. Semakin terbuka sebuah negara dalam perdagangan internasional (ekspor dan impor), maka akan semakin banyak FDI yang masuk ke negara tersebut (Jadhav, 2012).

\section{DATA DAN METODE}

\section{Data}

Data yang digunakan adalah data tahunan 2006-2014 di 32 propinsi di Indonesia yang bersumber dari Badan Koordinator Penanaman Modal (BKPM), Badan Pusat Statistik (BPS), dan Direktorat Jenderal Perimbangan Keuangan Kementerian Keuangan (DJPK Kemenkeu).

Variabel dependen yang digunakan yaitu realisasi FDI (triliyun rupiah), sedangkan variabel independen adalah proporsi pengeluaran belanja modal terhadap total belanja pemerintah daerah (dalam persen), jumlah angkatan kerja berpendidikan SMA keatas (dalam logaritma natural), tingkat keterbukaan perdagangan (dalam persen), proporsi ekspor migas dan mineral terhadap total ekspor (dalam persen), dan PDRB riil tahun dasar 2000 (dalam triliun rupiah).

\section{Metode}

Penelitian ini menggunakan metode regresi data panel untuk masing-masing koridor ekonomi Indonesia.

$$
\begin{aligned}
\mathrm{FDI}_{\text {ait }}= & \alpha_{0}+\beta_{1} \mathrm{BM}_{\text {ait }}+\beta_{2} \ln \mathrm{ANGKER}_{\text {ait }} \\
& +\beta_{3} \mathrm{OPEN}_{\text {ait }}+\beta_{4} \mathrm{XMIGAS}_{\text {ait }} \\
& +\beta_{5} \mathrm{PDRB}_{\text {ait }}+\varepsilon_{\text {ait }}
\end{aligned}
$$

\begin{tabular}{|c|c|}
\hline$a_{0}$ & intersep \\
\hline$\beta_{1}, \ldots, \beta_{5}$ & $\begin{array}{l}\text { koefisien regresi variabel } \\
\text { independen }\end{array}$ \\
\hline $\mathrm{FDI}_{\text {ait }}$ & $\begin{array}{l}\text { nilai realisasi FDI pada } \\
\text { koridor a propinsi i tahun } t \\
\text { (triliun rupiah) }\end{array}$ \\
\hline $\mathrm{BM}_{\text {ait }}$ & $\begin{array}{l}\text { proporsi nilai pengeluaran } \\
\text { belanja modal pemerintah } \\
\text { daerah dibagi dengan nilai } \\
\text { total pengeluaran belanja } \\
\text { pemerintah daerah pada } \\
\text { koridor a propinsi i tahun } \mathrm{t} \\
\text { (persen) }\end{array}$ \\
\hline ANGKER $_{\text {ait }}$ & $\begin{array}{l}\text { : jumlah angkatan kerja } \\
\text { berpendidikan tinggi pada } \\
\text { koridor a propinsi i tahun } \mathrm{t} \\
\text { (orang) }\end{array}$ \\
\hline $\mathrm{OPEN}_{\text {ait }}$ & $\begin{array}{l}\text { : tingkat keterbukaan } \\
\text { perdagangan pada koridor a } \\
\text { propinsi i tahun } \mathrm{t} \text { (persen) }\end{array}$ \\
\hline XMIGAS $_{\text {ait }}$ & $\begin{array}{l}\text { proporsi nilai ekspor minyak, } \\
\text { gas, dan mineral terhadap } \\
\text { nilai total ekspor pada koridor } \\
\text { a propinsi i tahun } \mathrm{t} \text { (persen } \\
\text { rupiah) }\end{array}$ \\
\hline $\mathrm{PDRB}_{\text {ait }}$ & $\begin{array}{l}\text { nilai Produk Domestik } \\
\text { Regional Bruto riil pada } \\
\text { koridor a propinsi i tahun } \mathrm{t} \\
\text { (triliun rupiah) }\end{array}$ \\
\hline$\varepsilon_{\text {ait }}$ & $\begin{array}{l}\text { : error term untuk koridor a } \\
\text { propinsi i tahun } \mathrm{t}\end{array}$ \\
\hline $\mathrm{a}$ & $\begin{array}{lr}\text { koridor } 1,2, \ldots, 6 & (1=\text { koridor } \\
\text { Sumatera, 2=koridor Jawa, } \\
\text { 3=koridor } & \text { Bali-Nusa } \\
\text { Tenggara, } & 4=\text { koridor } \\
\text { Kalimantan, } & 5=\text { koridor } \\
\text { Sulawesi, 6=koridor Maluku- } \\
\text { Papua) }\end{array}$ \\
\hline 1 & Aceh,..., Papua \\
\hline & : 2006,..., 2014 \\
\hline
\end{tabular}

\section{HASIL DAN PEMBAHASAN}

Total FDI yang direalisasikan di masing-masing koridor ekonomi dari tahun ke tahun terus mengalami peningkatan. Pada koridor Jawa, peningkatan tersebut diiringi dengan share FDI yang semakin menurun. Artinya, penanaman modal asing pada koridor di luar Jawa semakin berkembang dan merata.

di mana: 


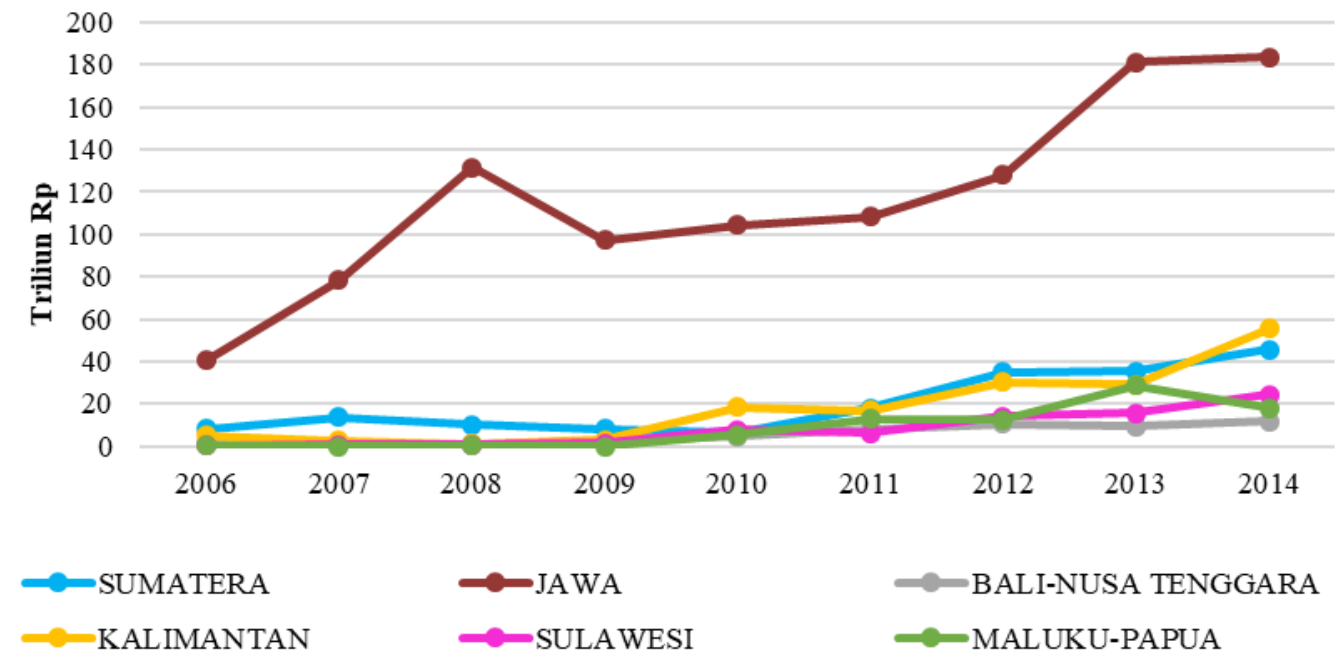

Sumber: Badan Koordinasi Penanaman Modal (BKPM, diolah)

\section{Gambar 2. Total FDI di Masing-Masing Koridor Ekonomi Indonesia Tahun 2006-2014}

Proporsi belanja modal terbesar berada di koridor Sumatera dan koridor Jawa. Akan tetapi, pemerintah daerah cenderung mengalokasikan belanja modal dengan proporsi yang sama setiap tahun. Beberapa koridor malah memiliki proporsi belanja modal yang cenderung menurun. Hanya koridor Jawa yang selama lima tahun terakhir memiliki proporsi belanja modal yang cenderung semakin membesar.

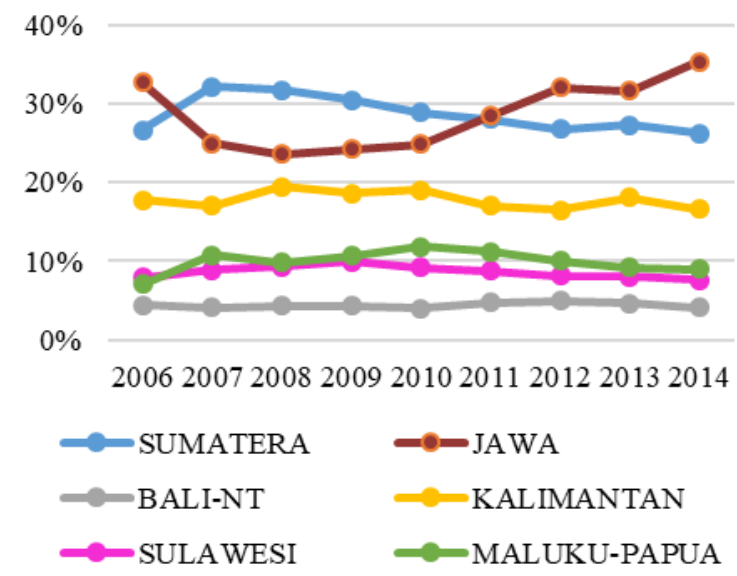

Sumber: Direktorat Jendral Perimbangan Keuangan Kementrian Keuangn (DJPK Kemenkeu, diolah)

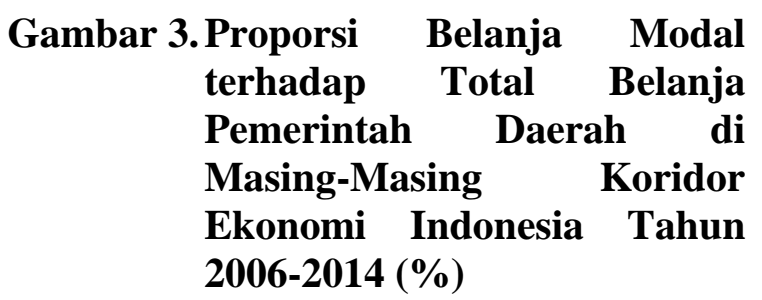

Jumlah tenaga kerja yang memiliki pendidikan tinggi di Indonesia dari tahun 2006-2014 terus mengalami peningkatan. Dari tahun ke tahun koridor Jawa selalu memiliki jumlah terbesar dibandingkan dengan koridor-koridor lain. Koridor Sumatera juga mempunyai jumlah angkatan kerja berpendidikan tinggi yang cukup banyak. Sebaliknya, koridor Kalimantan, Koridor Bali-Nusa Tenggara, Koridor Sulawesi, dan Koridor Maluku-Papua memiliki jumlah angkatan kerja berpendidikan tinggi yang masih sedikit.

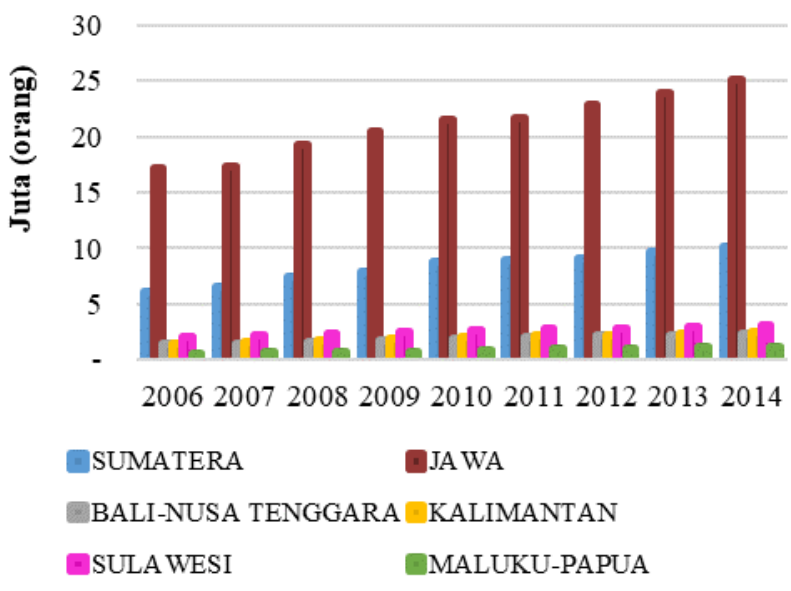

Sumber: BPS (diolah)

$\begin{array}{rrr}\text { Gambar 4. Jumlah Angkatan } & \text { Kerja } \\ \text { Berpendidikan Tinggi di } & \text { Tingi } \\ \text { Masing-Masing } & \text { Koridor } \\ & \text { Ekonomi Indonesia } & \text { Tahun } \\ & \text { 2006-2014 } & \end{array}$


Dari tahun 2006 hingga tahun 2014 jumlah nilai PDRB riil tertinggi adalah di koridor Jawa, yang pada tahun 2006 sebesar Rp1.081,4 triliyun, meningkat hingga menjadi Rp1.729,4 triliyun di tahun 2014. Sebaliknya, PDRB riil terkecil berada di koridor Maluku-Papua, yang mana pada tahun 2006 sebesar Rp29,75 triliyun menjadi Rp51,98 triliyun di tahun 2014. Dalam kurun waktu 9 tahun, PDRB koridor Maluku-Papua hanya meningkatkan share PDRB-nya dari sebesar $1,66 \%$ menjadi $1,78 \%$ dari total PDB nasional.

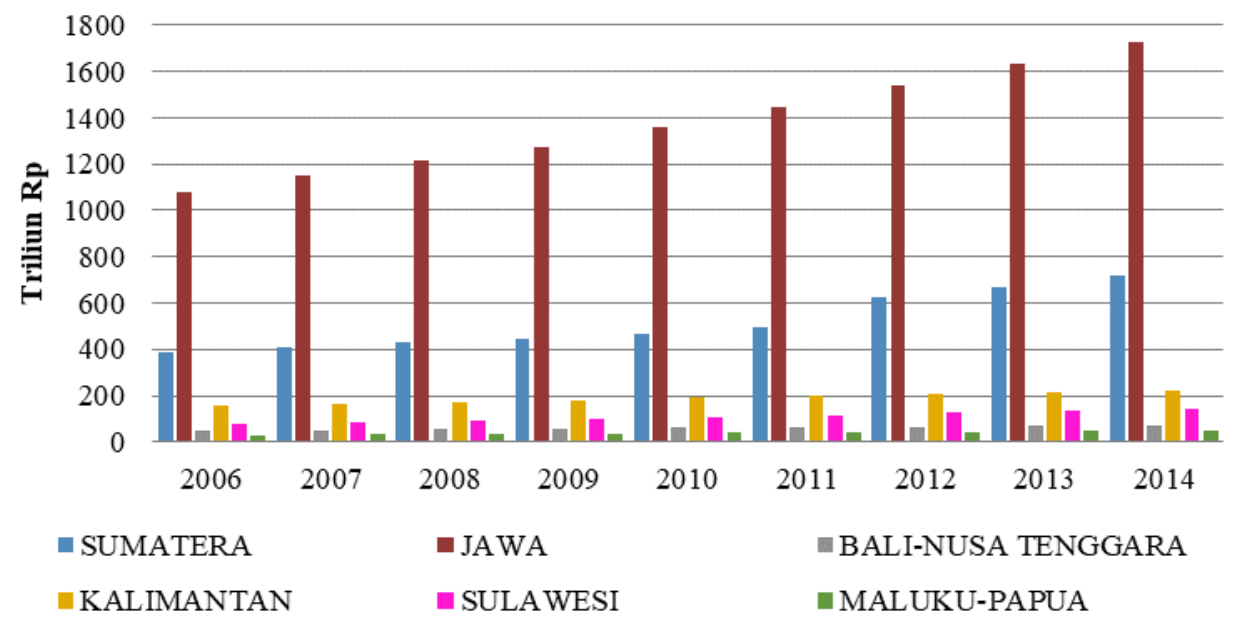

Sumber: BPS (diolah)

\section{Gambar 5. Nilai PDRB Atas Dasar Harga Konstan Tahun 2000 di Masing- Masing Koridor Ekonomi Indonesia Tahun 2006-2014}

Tingkat keterbukaan perdagangan koridor Kalimantan merupakan koridor yang paling tinggi, yaitu mencapai 0,82 di tahun 2014, sedangkan koridor Bali-Nusa Tenggara dan koridor Sulawesi merupakan koridor yang cenderung paling tertutup. Koridor Sumatera, koridor Jawa, dan koridor Maluku-Papua memiliki tingkat keterbukaan yang hampir sama, yaitu masih berfluktuatif sekitar 0,5.

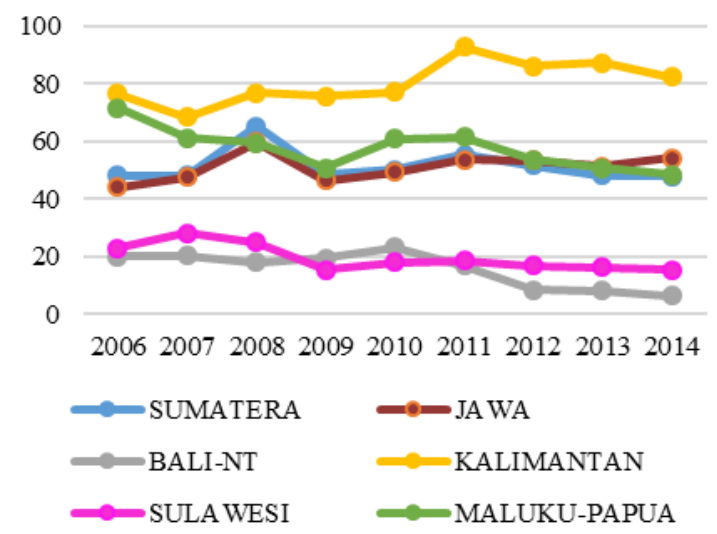

Gambar 6. Tingkat

Keterbukaan

Perdagangan

(Trade

Openness) di Masing-Masing Koridor Ekonomi Indonesia Tahun 2006-2014
Secara umum, koridor Maluku-Papua adalah koridor yang memiliki proporsi ekspor migas dan mineral tertinggi dibandingkan dengan koridor lain, sedangkan koridor Jawa adalah koridor dengan proporsi ekspor migas dan mineral terendah. Proporsi ekspor migas dan mineral koridor Maluku-Papua terhadap total eskpor koridor ini terus menurun, walaupun selalu lebih dari 99\% hingga tahun 2009. Di tahun 2014, proporsi eskpor migas dan mineral koridor ini masih sangat besar, yaitu 0,94 (atau 94\%).

Analisis inferensia dengan model regresi data panel menunjukkan bahwa model yang terpilih untuk koridor Sumatera yaitu Fixed Effect Model dengan SeeminglyUnrelated Regression (FEMSUR), begitu juga untuk model koridor Jawa dan Sulawesi. Sedangkan untuk koridor Bali-Nusa Tenggara hanya menggunakan Fixed Effect Model. Untuk koridor Kalimantan menggunakan Fixed Effect Model dengan Weighted Least Square (FEM-WLS). Sedangkan pada koridor Maluku-Papua terpilih model Common 
Effect Model dengan Weighted Least Square (CEM-WLS).

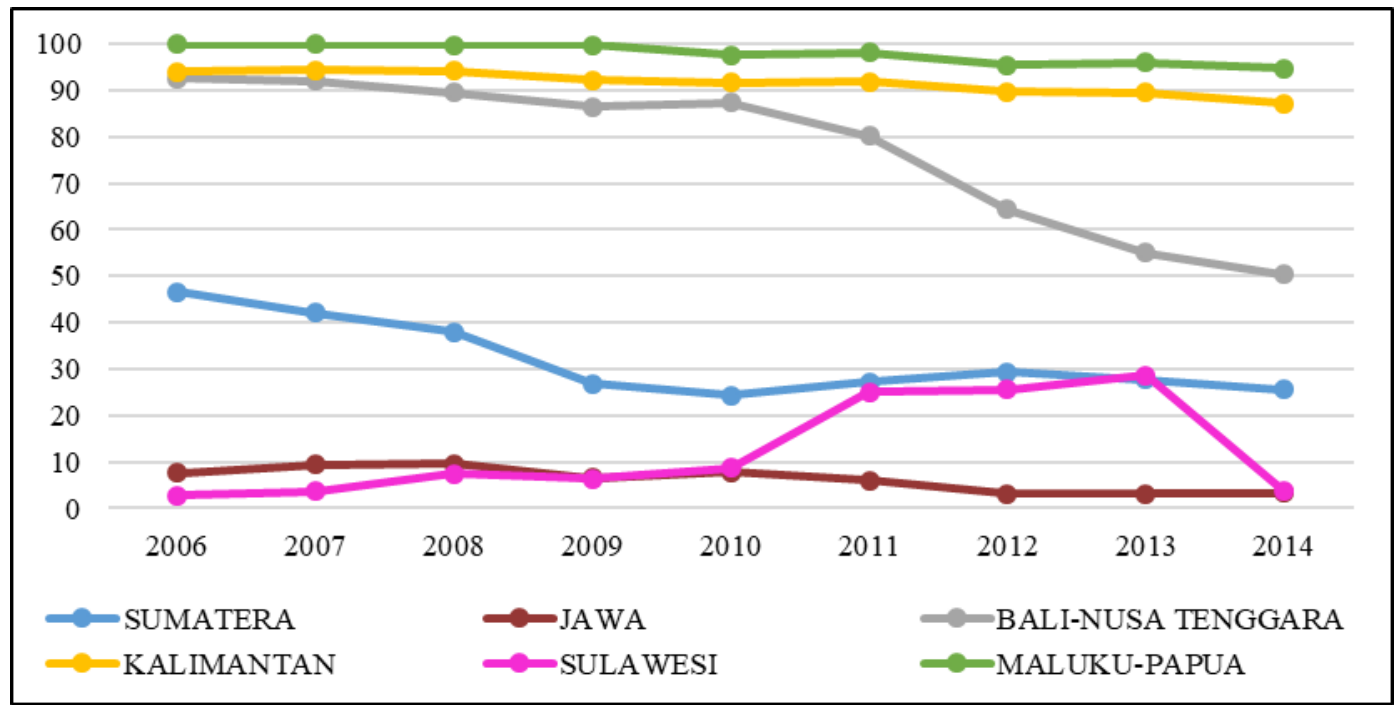

Gambar 7.Proporsi Ekspor Migas dan Mineral terhadap Total Ekspor di Masing-Masing Koridor Ekonomi Indonesia Tahun 2006-2014

Analisis inferensia dengan model regresi data panel menunjukkan bahwa model yang terpilih untuk koridor Sumatera yaitu Fixed Effect Model dengan SeeminglyUnrelated Regression (FEMSUR), begitu juga untuk model koridor Jawa dan Sulawesi. Sedangkan untuk koridor Bali-Nusa Tenggara hanya menggunakan
Fixed Effect Model. Untuk koridor Kalimantan menggunakan Fixed Effect Model dengan Weighted Least Square (FEM-WLS). Sedangkan pada koridor Maluku-Papua terpilih model Common Effect Modeldengan Weighted Least Square (CEM-WLS).

Tabel 1. Hasil estimasi untuk masing-masing koridor ekonomi

\begin{tabular}{|c|c|c|c|c|c|c|}
\hline Variabel ${ }^{\text {Koridor }}$ & Sumatera & Jawa & $\begin{array}{l}\text { Bali-Nusa } \\
\text { Tenggara }\end{array}$ & Kalimantan & Sulawesi & $\begin{array}{l}\text { Maluku- } \\
\text { Papua }\end{array}$ \\
\hline R-square & 0.54128 & 0.83090 & 0.83964 & 0.74482 & 0.73076 & 0.32286 \\
\hline F-statistik & 0.47534 & 0.83410 & 0.83964 & 0.79079 & 0.65064 & 0.32329 \\
\hline Prob. & 0.00000 & 0.00000 & 0.00000 & 0.00000 & 0.00000 & 0.00431 \\
\hline \multicolumn{7}{|l|}{ Koefisien: } \\
\hline - Kontanta & -19.78570 & -214.68580 & 6.59222 & -35.58441 & -31.86938 & 22.41631 \\
\hline - $\mathbf{B M}$ & $\begin{array}{r}-0.04195 * \\
(0,0205) \\
\end{array}$ & $\begin{array}{r}-0.53512 * \\
(0,0143) \\
\end{array}$ & $\begin{array}{r}-0.03111 \\
(0,5204) \\
\end{array}$ & $\begin{array}{l}0.01272 \\
(0,8501)\end{array}$ & $\begin{array}{r}-0.03072 * \\
(0,0756)\end{array}$ & $\begin{array}{r}-0.07743 \\
(0,2800)\end{array}$ \\
\hline - LNANGKER & $\begin{array}{r}1.87009 * \\
(0,0039) \\
\end{array}$ & $\begin{array}{r}14.62105^{*} \\
(0,0587) \\
\end{array}$ & $\begin{array}{r}-0.66160 \\
(0,7486) \\
\end{array}$ & $\begin{array}{r}0.41216 \\
(0,9413)\end{array}$ & $\begin{array}{r}2.52456 * \\
(0,0130) \\
\end{array}$ & $\begin{array}{r}-1.75210 \\
(0,3818) \\
\end{array}$ \\
\hline - OPEN & $\begin{array}{r}-0.03082 * \\
(0,0611)\end{array}$ & $\begin{array}{r}0.03064 \\
(0,8894)\end{array}$ & $\begin{array}{r}-0.16459 * \\
(0,0000)\end{array}$ & $\begin{array}{r}0.00598 \\
(0,2373)\end{array}$ & $\begin{array}{r}-0.11929 * \\
(0,0026)\end{array}$ & $\begin{array}{r}-0.16917 * \\
(0,0015)\end{array}$ \\
\hline - XMIGAS & $\begin{array}{r}-0.02881 * \\
(0,0463)\end{array}$ & $\begin{array}{c}0.10944 \\
(0,3430)\end{array}$ & $\begin{array}{r}-0.00702 \\
(0,5924)\end{array}$ & $\begin{array}{r}-0.06619 * \\
(0,0123)\end{array}$ & $\begin{array}{r}0.02729 * \\
(0,0105)\end{array}$ & $\begin{array}{r}0.06167 * \\
(0,0490)\end{array}$ \\
\hline - PDRB & $\begin{array}{r}0.00892 * \\
(0,0032)\end{array}$ & $\begin{array}{r}0.10077 * \\
(0,0000)\end{array}$ & $\begin{array}{r}0.42783 * \\
(0,0015)\end{array}$ & $\begin{array}{r}0.78313^{*} \\
(0,0008)\end{array}$ & $\begin{array}{r}0.12673^{*} \\
(0,0001)\end{array}$ & $\begin{array}{r}0.46480 * \\
(0,0010)\end{array}$ \\
\hline
\end{tabular}

\footnotetext{
*signifikan pada level 5\%
} 
Berdasarkan hasil analisis inferensia, proporsi belanja modal, jumlah angkatan kerja berpendidikan tinggi, dan tingkat keterbukaan perdagangan mempunyai pengaruh yang berbeda-beda di masingmasing koridor ekonomi Indonesia.

Proporsi belanja modal pemerintah daerah hanya berpengaruh signifikan terhadap FDI di koridor Sumatera, koridor Jawa, dan koridor Sulawesi. Sedangkan di koridor Bali dan Nusa Tenggara, koridor Kalimantan, dan koridor Maluku dan Papua, proporsi belanja modal pemerintah daerah tidak berpengaruh signifikan terhadap FDI.

Sebaliknya, jumlah angkatan kerja berpendidikan tinggi berpengaruh signifikan dan positif terhadap FDI di koridor Sumatera, koridor Jawa, dan koridor Sulawesi. Hal ini kemungkinan terjadi karena koridor Jawa dan koridor Sumatera memiliki jumlah angkatan kerja berpendidikan tinggi terbanyak. Sedangkan koridor Sulawesi memiliki proporsi angkatan kerja berpendidikan tinggi terbesar dibandingkan dengan koridor-koridor lain.

Di samping itu, seperti halnya variabel proporsi belanja modal, jumlah angkatan kerja berpendidikan tinggi juga tidak berpengaruh signifikan terhadap FDI di koridor Bali dan Nusa Tenggara, koridor Kalimantan, dan koridor Maluku dan Papua.

Tingkat keterbukaan perdagangan berpengaruh negatif dan signifikan terhadap FDI di koridor Sumatera, koridor Bali dan Nusa Tenggara, koridor Sulawesi, dan koridor Maluku dan Papua. Sedangkan di koridor Jawa dan koridor Kalimantan, tingkat keterbukaan perdagangan tidak berpengaruh signifikan terhadap FDI.

Pengaruh tingkat keterbukaan perdagangan terhadap FDI tergantung pada jenis FDI yang masuk ke wilayah tersebut. Pada market seeking FDI, tingkat keterbukaan perdagangan akan cenderung untuk berpengaruh negatif terhadap FDI. Hal tersebut biasa terjadi pada negara-negara maju, yang mana cenderung memiliki tingkat keterbukaan yang lebih kecil dibandingkan dengan negara-negara berkembang (Briguglio, 2016). Sebaliknya, pada resource seeking FDI, tingkat keterbukaan perdagangan cederung berpengaruh positif terhadap FDI. Akan tetapi, tingkat keterbukaan bisa berpengaruh terhadap FDI bertipe market seeking apabila pasar yang dicari oleh investor bukan hanya berada di dalam wilayah tersebut, melainkan juga wilayah disekitarnya.

Motivasi market seeking dan resource seeking di setiap koridor ekonomi Indonesia disimpulkan berdasarkan signifikansi dan pengaruh variabel-variabel proksi terhadap FDI. Adanya motivasi market seeking dan resource seeking adalah apabila variabelvariabel proksi untuk market size dan natural resource availability, yaitu PDRB dan proporsi ekspor migas dan mineral, berpengaruh signifikan dan positif terhadap FDI.

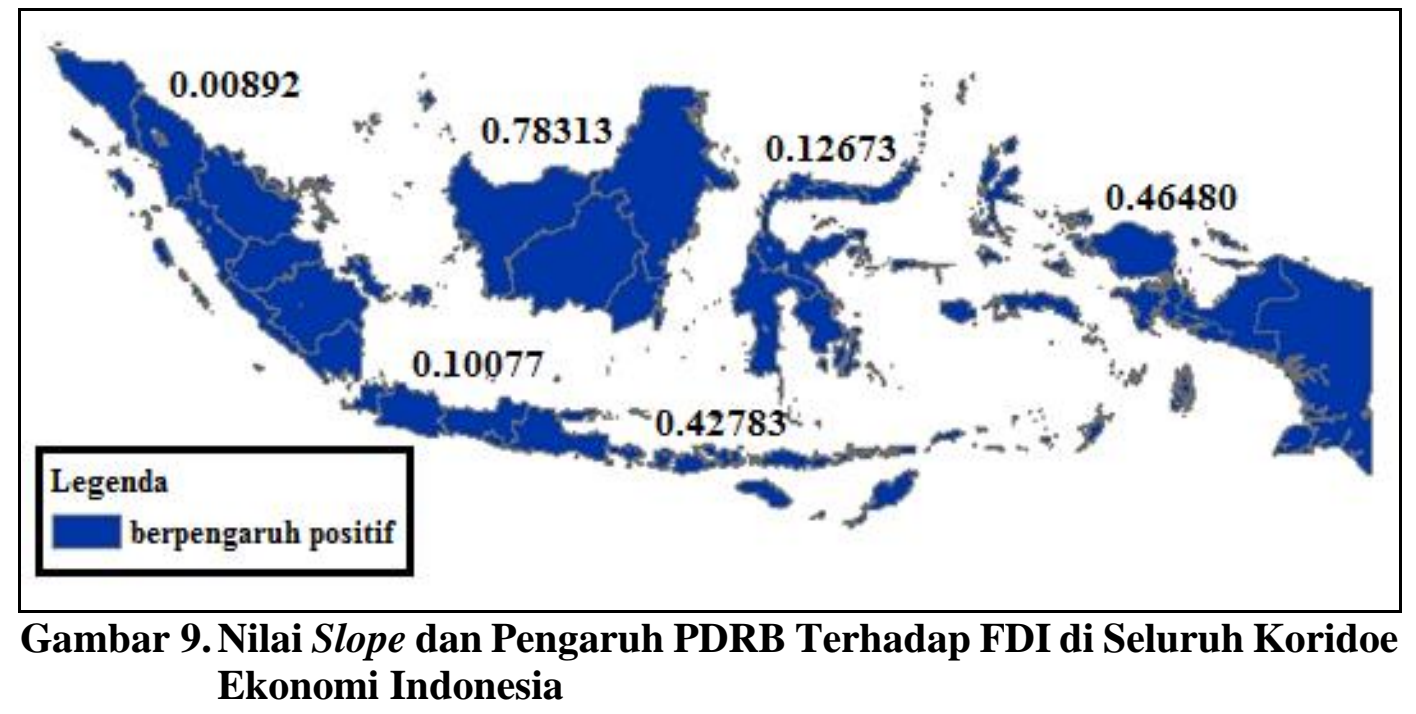

38 | Jurnal Aplikasi Statistika \& Komputasi Statistik V.9.1.2017, ISSN 2086-4132 
Dari hasil pengujian signifikansi variabel untuk masing-masing koridor, variabel proksi untuk market size, yaitu PDRB, signifikan dan positif di semua koridor. Hasil tersebut mengindikasikan bahwa tipe FDI yang masuk ke masing- masing koridor di Indonesia bersifat market seeking. Hal ini didukung dengan tidak signifikannya variabel proksi untuk natural resource availability, yaitu proporsi ekspor migas dan mineral di koridor Jawa dan koridor Bali dan Nusa Tenggara.

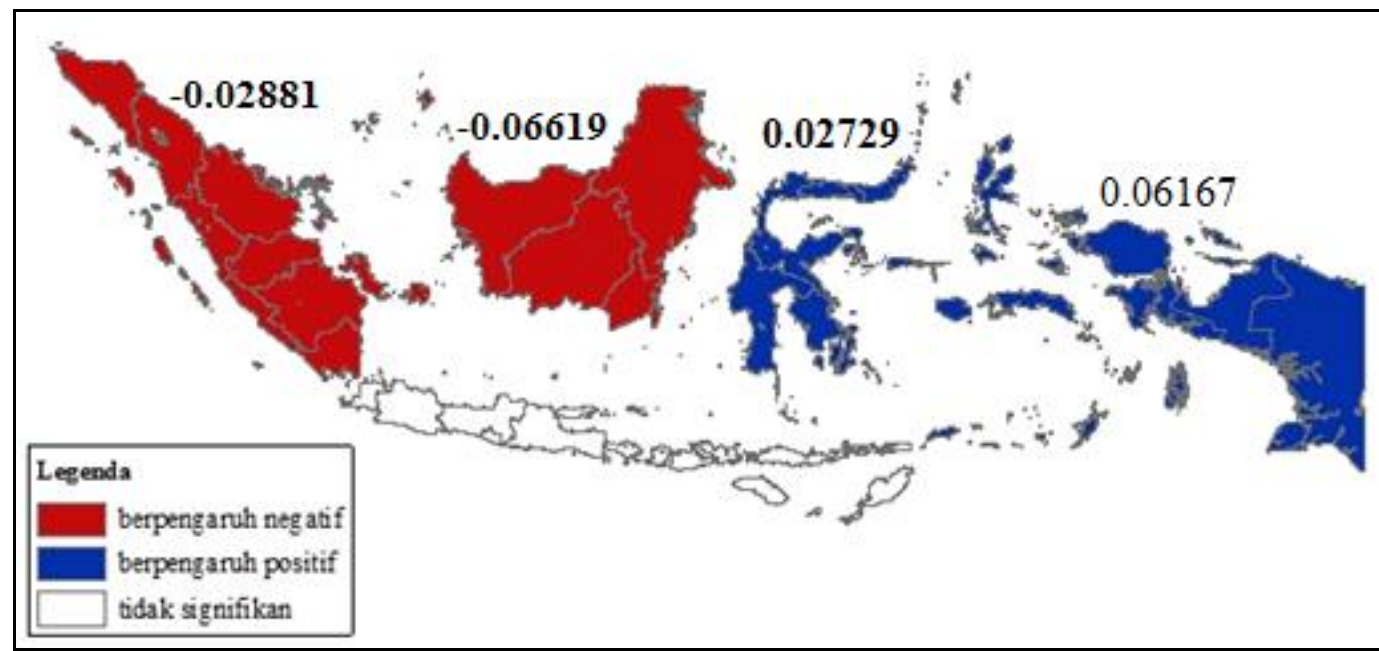

Gambar 10. Nilai Slope dan Pengaruh Proporsi Ekspor Migas dan Mineral Terhadap FDI di Seluruh Koridor Ekonomi Indonesia

Variabel proporsi migas dan mineral berpengaruh negatif terhadap realisasi FDI di koridor Sumatera. Hal tersebut berarti bahwa FDI yang masuk ke koridor Sumatera bukanlah tipe resource seeking. Hasil serupa juga didapatkan di koridor Kalimantan, yang mana natural resource availability juga menunjukkan hasil signifikan namun negatif. Hasil ini berbeda dengan fungsi koridor Kalimantan yang merupakan sentra produksi dan pengolahan hasil tambang yang seharusnya merupakan faktor penarik utama bagi investor untuk menanamkan modalnya disana.

Di sisi lain, natural resource availability menunjukkan hasil yang signifikan dan positif di koridor Sulawesi dan koridor Maluku dan Papua. Hal ini menunjukkan bahwa, selain FDI yang bertipe market seeking, ada juga FDI yang masuk ke koridor Sulawesi dan koridor Maluku-Papua dengan tipe resource seeking. Hal ini sesuai dengan hipotesis bahwa FDI yang masuk ke koridor MalukuPapua akan bertipe resouce seeking karena sumber daya alamnya yang masih melimpah.

\section{KESIMPULAN DAN SARAN}

Perkembangan realisasi FDI masih didominasi oleh koridor Jawa, namun dikoridor lain sudah mulai tumbuh. Pengeluaran belanja modal, jumlah angkatan kerja berpendidikan tinggi, dan PDRB juga masih didominasi oleh koridor Jawa. Tingkat keterbukaan perdagangan yang paling tertinggi berada di koridor Kalimantan. Sedangkan proporsi ekspor migas dan mineral terbesar ada di koridor Maluku dan Papua.

Faktor-faktor yang memengaruhi FDI berbeda-beda untuk masing-masing koridor. Di koridor Sumatera, koridor Jawa, dan koridor Sulawesi, belanja modal berpengaruh negatif terhadap realisasi FDI, sedangkan jumlah angkatan kerja memiliki pengaruh yang positif. Faktor tingkat keterbukaan perdagangan berpengaruh negatif di koridor Sumatera, koridor Bali dan Nusa Tenggara, koridor Sulawesi, dan koridor Maluku dan Papua. Di koridor Sumatera dan koridor Kalimantan, ekspor migas dan mineral berpengaruh negatif terhadap realisasi FDI, sebaliknya ekspor migas berpengaruh positif terhadap realisasi FDI di koridor Sulawesi dan koridor Maluku 
dan Papua. PDRB berpengaruh positif terhadap realisasi FDI di semua koridor ekonomi.

FDI yang bermotivasi market seeking ditemukan di semua koridor ekonomi Indonesia. Sementara itu, FDI dengan motivasi resource seeking hanya ditemukan di koridor Sulawesi dan koridor Maluku dan Papua.

Pemerintah perlu mengevaluasi penggunaan pengeluaran belanja modal daerah agar tepat sasaran. Pemerintah juga perlu meningkatkan kebijakan tentang pendidikan, terutama untuk pendidikan tinggi, dan kebijakan yang dapat meningkatkan PDRB. Selain itu, pemerintah perlu mencari alternatif pengganti sumber daya alam di Maluku-Papua yang masih menjadi incaran para investor asing agar bisa dimanfaatkan dengan baik dan menghasilkan nilai tambah yang akan lebih menguntungkan wilayah setempat. Selain itu, motivasi resource seeking yang masih ditemukan di koridor Maluku-Papua juga belum sesuai dengan tujuan pemerintah yang ingin mengembangkan kegiatan ekonomi di masing-masing wilayah Indonesia.

\section{DAFTAR PUSTAKA}

Asiedu, E. 2002. On the Determinants of Foreign Direct Investment to Developing Countries: Is Africa Different?. World Development. 30(1), 107-119. (diakses 2 Agustus 2016). people.ku.edu/ asiedu/FDI-inAfrica-WD.pdf

Asiedu, E. 2006. Foreign Direct Investment in Africa: The Role of Natural Resources, Market Size, Government Policy, Institutions and Political Instability. working paper. United Nation University. (diakses 25 Juni 2016). people.ku.edu/ asiedu/worldeconomy.pdf

Asiedu, E. dan Lien, D.D. 2010. Democracy, Foreign Direct Investment and Natural Resources. Working paper. (diakses 1 Agustus 2016). http://papers.ssrn.com/sol3/papers.cf $\underline{\text { m?abstract_id }=1726587}$
Badan Pusat Statistik. (2006-2014). Keadaan Angkatan Kerja di Indonesia. Jakarta: BPS

Badan Pusat Statistik. (2007-2015). Statistik Indonesia. Jakarta: BPS

Briguglio, L. 2016. Small States And The European Union: Economic Perspectives New York: Routledge

Dunning, J. H. 1993. The Globalization of Business. (diaskses 25 Juni 2016). http://unctad.org/en/PublicationChapt ers/iteiitv3n1a3 en.pdf

Jadhav, P. 2012. Determinants of Foreign Direct Investment in BRICS economies: Analysis of Economics, Institutional, and Political Factor. Procedia - Social and Behavioral Science. 37, 5-14. (diakses 26 Januari 2016).

http://www.sciencedirect.com/science /article/pii/S1877042812007495

Kemenkeu. 2011. Klasifikasi Jenis Belanja. (diakses 29 Juni 2016). http://www.jdih.kemenkeu.go.id/fullT ext/2011/101 PMK.02 2011PerLam $\mathrm{p} \% 20 \mathrm{III}$

Rohmana, Y. 2011. Analisis Faktor-Faktor yang Mempengaruhi Investasi Asing Langsung di Indonesia Periode 19802008. Jurnal Sains dan Terapan. 6(2). Universitas Pendidikan Indonesia (UPI) Bandung. (diakses 8 Februari 2015).

http://jurnal.upi.edu/2022/view/1119/ analisis-faktor-faktor-yangmempengaruhi-investasi-asinglangsung-di-indonesia-periode-19802008.html

Sarwedi. 2002. Investasi Asing Langsung di Indonesia dan Faktor yang Mempengaruhinya. Jurnal Akuntansi \& Keuangan. 4(1), 17-35 Jurusan Ekonomi Akuntansi, Fakultas Ekonomi - Universitas Kristen Petra.

Setiawan, G. 2002. The Impact of Foreign Direct Investment on Indonesian Economic Growth. Tesis. Seoul: KDI (Korea Development Institute) School of Public Policy and Management.

Todaro, M.P. dan Smith, S.C. 2003. Pembangunan Ekonomi di Dunia Ketiga: Jilid 1. Jakarta: Erlangga. 